\title{
Synthesis and Structure of Benzotriazolyl Fluorenes
}

\author{
Kwanghee Koh Park, Hyemi Jung, Taewoo Lee, and Sung Kwon Kang \\ Department of Chemistry, Chungnam National University, Daejeon 305-764, Korea. *E-mail: khkoh@cnu.ac.kr \\ Received March 16, 2010, Accepted March 27, 2010
}

\begin{abstract}
1-(Fluoren-2-yl)-benzo[ $d][1,2,3]$ triazoles 5a-b were synthesized starting from 2-nitrofluorene. 2-Nitrofluorenes 1a-b were reduced by catalytic hydrogenation, reacted with 2,4-dinitrofluorobenzene followed by catalytic hydrogenation to afford 2-( $N$-2,4-diaminophenyl)aminofluorenes 4a-b. Diazotization of $\mathbf{4 a - b}$ with $\mathrm{NaNO}_{2} / \mathrm{H}_{2} \mathrm{SO}_{4}$ followed by treatment with $\mathrm{H}_{3} \mathrm{PO}_{2}$ gave 5a-b. Sulfonation of 5a-b yielded 7-benzotriazol-1-yl-fluorene-2-sulfonic acids $\mathbf{6 a - b}$. The structures of $\mathbf{5 b}$ and $\mathbf{6} \mathbf{b}$ were firmly identified by X-ray crystal analysis in addition to ${ }^{1} \mathrm{H} \mathrm{NMR},{ }^{13} \mathrm{C}$ NMR, and elemental analysis.
\end{abstract}

Key Words: 2-Aminofluorenes, 2-( $N$-2,4-Dinitrophenyl)aminofluorenes, 2-( $N$-2,4-Diaminophenyl)aminofluorenes, 1-(Fluoren-2-yl)-benzo[ $d][1,2,3]$ triazoles, 7-Benzotriazol-1-yl-fluorene-2-sulfonic acids

\section{Introduction}

The fluorene ring is a $\pi$-conjugated system that enables facile synthetic manipulation. The synthesis and characterization of fluorene derivatives have attracted much attention in recent years because of their interesting properties and potential applications in various fields, such as two-photon absorption dyes, ${ }^{1-9}$ fluorescent probes, ${ }^{10-17}$ and light-emitting materials. ${ }^{18-21}$ It has also been shown that fluorene derivatives exhibit high binding affinity to human serum albumin, ${ }^{13} \beta_{2}$-integrins, ${ }^{22}$ and $\beta$-amyloid. $^{23}$ These diverse applications of fluorene derivatives led us to explore synthesis of novel functional fluorene molecules.

Derivatization of the fluorene ring has mostly been carried out at 2, 7, and 9 positions. Alkylation at the 9-position of the fluorene ring can be easily carried out utilizing the acidity of the hydrogens at the 9-position, 5,6,9,13-16,21 and introduction of substituents at 2- or 7-position was also effectively accomplished by electrophillic substitution of the fluorene ring., $5,9,12-15,21$ Further manipulation at 2- or 7-position has been carried out by standard procedures starting from the appropriate fluorene compounds having diversely transformable substituents such as nitro and/or halogen group. In particular, various metal-catalyzed coupling reactions of bromo- or iodo-fluorenes with stannyl compounds (Stille reaction), ${ }^{1,9}$ alkenes (Heck reaction), ${ }^{1-3,5,6,15,16}$ arylboronic acid (Suzuki reaction), ${ }^{10,18,21}$ terminal alkynes (Sonogashira reaction), ${ }^{10}$ or amines (Buchwald-Hartwig or Ullmann reaction $)^{5,9,16}$ provided a variety of alkenyl-, aryl-, alkynyl-, or amino-substituted fluorene derivatives. However, further diversification of fluorene compounds is still highly desirable for the search of fluorene compounds of novel functionality.

The fluorene derivatives having heterocycle as a substituent have rarely been prepared: to the best of our knowledge, benzothiazole is an only example of heterocyclic substituents. ${ }^{8-9}$ The benzothiazole-substituted fluorenes were prepared by coupling the preformed benzothiazole ring with fluorene derivatives. ${ }^{8-9}$

In this paper, we report the synthesis of new fluorene derivatives $\mathbf{5}$ having benzotriazole as a substituent via in situ formation of the heterocyclic ring. Introduction of sulfonic acid group to $\mathbf{5}$ gave water-soluble benzotriazole-substituted fluo- renes 6. Benzotriazole ring-containing compounds have been reported to show various biological activities such as potential inhibitors of protein kinase CK2, ${ }^{24}$ cytosolic phospholipase $\mathrm{A}_{2} \alpha,{ }^{25}$ and cytochrome P450 14 $\alpha$-demethylase. ${ }^{26}$
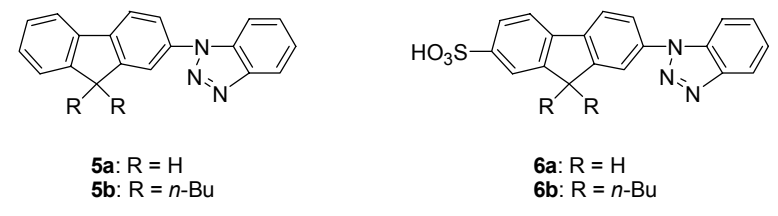

Results and Discussion

The synthetic pathway for the fluorene derivatives bearing benzotriazole substituent starting from 2-nitrofluorene 1a or 2-nitro-9,9-dibutylfluorene $\mathbf{1 b}$ is shown in Scheme 1. The compound $1 \mathbf{b}$ was prepared by reacting $1 \mathrm{a}$ with $n$-butyl bromide in DMF using cesium carbonate as a base as described previously. ${ }^{13}$ Reduction of nitro group of $\mathbf{1 a - b}$ with atmospheric hydrogen gas in the presence of $5 \% \mathrm{Pd} / \mathrm{C}$ at room temperature provided the corresponding 2-aminofluorenes $\mathbf{2 a - b}$ in $85 \sim 96 \%$ yields. Nucleophilic aromatic substitution of 2,4-dinitrofluorobenzene with 2-aminofluorenes 2a-b in DMSO at room temperature yielded 2-( $N$-2,4-dinitrophenyl)aminofluorene compounds 3a-b in $90 \sim 97 \%$ yields. Catalytic reduction of the two nitro groups of $\mathbf{3 a - b}$ with atmospheric hydrogen gas in the presence of $5 \%$ $\mathrm{Pd} / \mathrm{C}$ at room temperature gave the corresponding 2-(N-2,4diaminophenyl)aminofluorene compounds $\mathbf{4 a - b}$. Treatment of 4a-b with $\mathrm{NaNO}_{2} / \mathrm{H}_{2} \mathrm{SO}_{4}$ at $0 \sim 5^{\circ} \mathrm{C}$ followed by treatment with $\mathrm{H}_{3} \mathrm{PO}_{2}$ at $0 \sim 5^{\circ} \mathrm{C}$ and then room temperature gave 1-(fluoren2-yl)-benzo $[d][1,2,3]$ triazoles 5a-b. The overall yields of 5a-b starting from 3a-b were $30 \sim 32 \%$. Sulfonation of 5a-b with concentrated sulfuric acid at room temperature provided 7-benzotriazol-1-yl-fluorene-2-sulfonic acids 6a-b in $78 \sim 97 \%$ yields. The structures of all the new compounds were characterized by ${ }^{1} \mathrm{H} \mathrm{NMR},{ }^{13} \mathrm{C} \mathrm{NMR}$, and elemental analysis except for $\mathbf{4 a - b}$ : elemental analysis of $\mathbf{4 a - b}$ was not carried out due to their lack of enough stability. 
<smiles></smiles>

1a: $\mathrm{R}=\mathrm{H}$ 1b: $\mathrm{R}=n-\mathrm{Bu}$

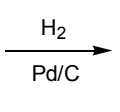<smiles>[R]C1([R])c2ccccc2-c2ccc(N)cc21</smiles>

2a: $\mathrm{R}=\mathrm{H}$

2b: $\mathrm{R}=n-\mathrm{Bu}$

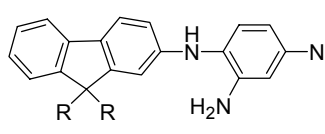

4a: $\mathrm{R}=\mathrm{H}$ 4b: $\mathrm{R}=n-\mathrm{Bu}$

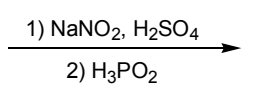

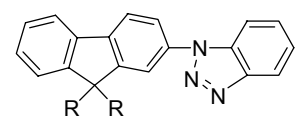

5a: $\mathrm{R}=\mathrm{H}$ 5b: $\mathrm{R}=n-\mathrm{Bu}$

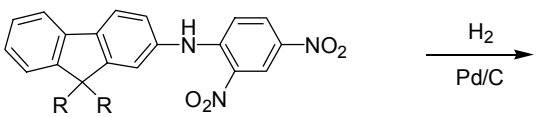

3a: $\mathrm{R}=\mathrm{H}$

3b: $\mathrm{R}=n-\mathrm{Bu}$

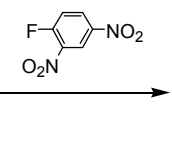

conc $\mathrm{H}_{2} \mathrm{SO}_{4}$

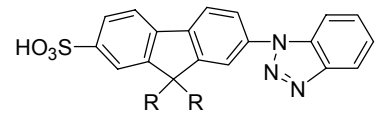

6a: $\mathrm{R}=\mathrm{H}$

6b: $\mathrm{R}=n-\mathrm{Bu}$

Scheme 1. Synthetic pathway of benzotriazolyl fluorene derivatives

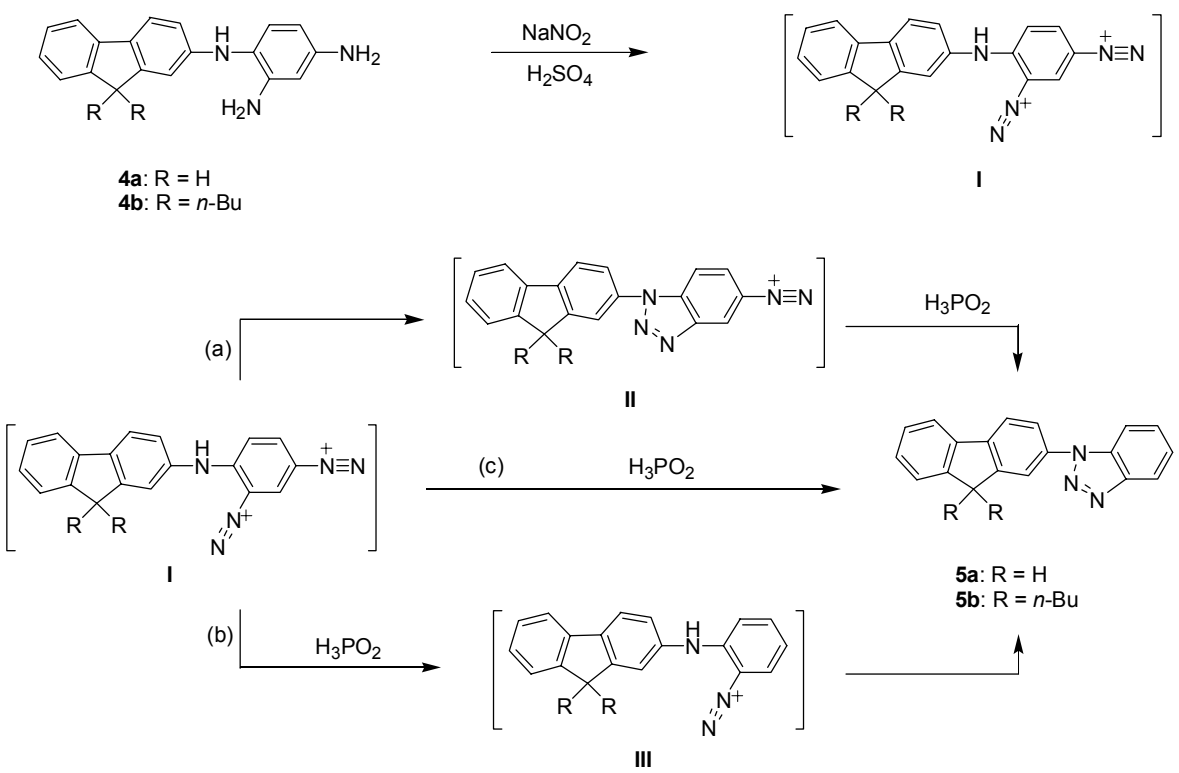

Scheme 2. Possible mechanisms for conversion of $\mathbf{4 a - b}$ to $\mathbf{5 a - b}$

The conversion of $\mathbf{4 a - b}$ to $\mathbf{5} \mathbf{a}-\mathbf{b}$ indicates that the introduction of benzotriazole moiety as a substituent of the fluorene ring is accomplished through in situ formation of the heterocycle. It seems to occur via diazotization of both amino groups to diazonium group to give intermediate $\mathbf{I}$ and then the reaction of $p$-diazonium group with hypophosphorus acid and the coupling of $o$-diazonium group with the adjacent secondary amino group at the 2-position of the fluorene ring. The possible mechanisms for the transformation are shown in Scheme 2: the replacement of the diazonium group by hydrogen atom and the coupling reaction to form the triazole ring can occur sequentially as shown in (a) and (b) or concurrently as in (c). The exact mechanism of the reaction is not clear at this point, and its clarification is beyond the scope of this work. We also attempted the reaction of 2-aminofluorenes $\mathbf{2 a - b}$ with 2-nitrofluorobenzene instead of 2,4-dinitrofluorobenzene for the synthesis of $\mathbf{5 a - b}$, but the nucleophilic substitution reaction of the former compound by 2-aminofluorenes was quite sluggish even at $100 \sim$ $110^{\circ} \mathrm{C}$ and gave complex mixtures.

It is worth to mention that ${ }^{1} \mathrm{H}$ NMR spectra of 9,9-dibutylated fluorene compounds $\mathbf{1 b}$-6b show interesting features in the alkyl region. All of them show a similar pattern of the peaks corresponding to the butyl groups, which are composed of four-proton multiplet (for the compounds $\mathbf{1 b},{ }^{13} \mathbf{2 b}, \mathbf{4 b}$, and $\mathbf{5 b}$ ) or quintet (for $3 \mathbf{b}$ and $\mathbf{6 b}$ ) at $\delta$ 0.4-0.7, six-proton triplet at $\delta 0.6-0.7$, fourproton sextet at $\delta 1.0-1.1$, and four-proton multiplet at $\delta 1.7-2.2$. The portion of the spectrum of $\mathbf{5 b}$ is given as a typical example in Figure 1. One noticeable feature of the butyl peaks of $\mathbf{1 b - 6 \mathbf { b }}$ is the unusually up-field multiplet (or quintet) at $\delta$ 0.4-0.7 $\left(-\mathrm{CH}_{2} \mathrm{CH}_{2} \mathrm{CH}_{2} \mathrm{CH}_{3}\right)$ and triplet at $\delta$ 0.6-0.7 $\left(-\mathrm{CH}_{2} \mathrm{CH}_{2} \mathrm{CH}_{2} \mathrm{CH}_{3}\right)$. These up-field shifts indicate that these protons lie in the shielding region generated by ring current of the aromatic nucleus. ${ }^{27}$ The other feature is the multiplet signal at $\delta$ 1.7-2.2 $\left(-\mathrm{CH}_{2} \mathrm{CH}_{2}\right.$ $\mathrm{CH}_{2} \mathrm{CH}_{3}$ ) rather than a usual triplet, which implies that the protons are diastereotopic. The diastereotopic protons have different chemical shifts and the proton is split by the other proton attached to the same carbon as well as the two protons attached to the next carbon. ${ }^{27 \mathrm{~b}}$ The peaks at $\delta 1.97-2.18$ in Figure 1 can be viewed as two separate peaks centered at $\delta 2.02$ and 2.12 , respectively, and each peak is split into a doublet (by the other 


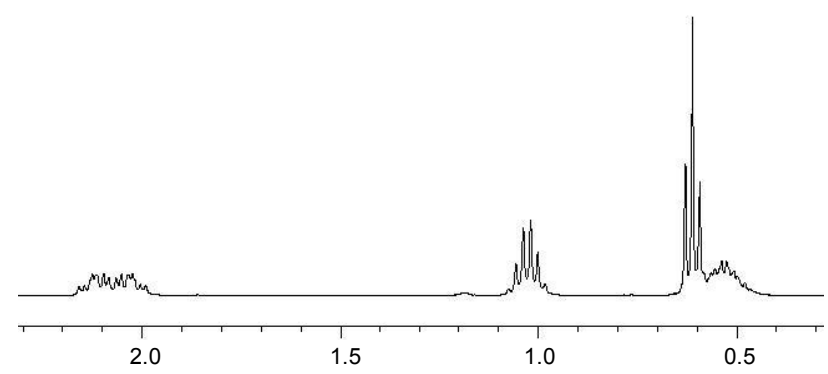

Figure 1. The portion of the ${ }^{1} \mathrm{H}$ NMR spectrum corresponding to the butyl group of $\mathbf{5 b}$.
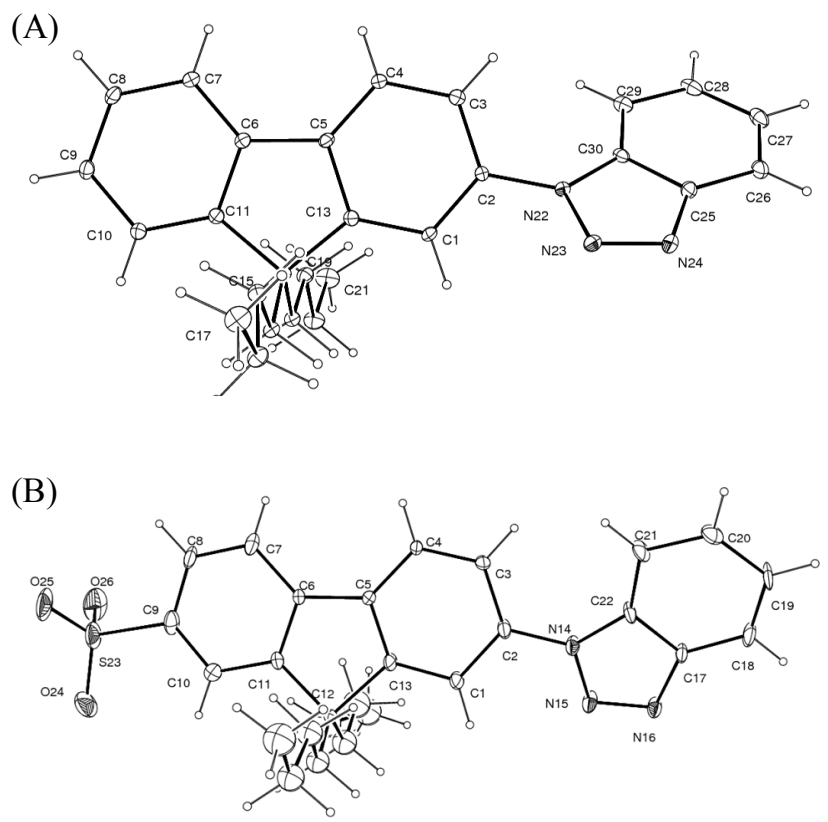

Figure 2. ORTEP diagrams of the compounds $5 \mathbf{b}(\mathrm{A})$ and $6 \mathbf{b}(\mathrm{B})$.

proton attached to the same carbon) of a triplet (by the two protons attached to the next carbon). It turned out that the methylene protons $\left(-\mathrm{CH}_{2} \mathrm{CH}_{2} \mathrm{CH}_{2} \mathrm{CH}_{3}\right)$ next to the aforementioned methylene group appear either as a multiplet (for the compounds $\mathbf{1 b},{ }^{13} \mathbf{2 b}, \mathbf{4 b}$, and $\mathbf{5 b}$ ) or as a quintet (for $3 \mathbf{b}$ and $\mathbf{6 b}$ ) at $\delta 0.4-0.7$ depending on the detailed structure of the compound.

The structures of 1-(9,9-dibutylfluoren-2-yl)-benzo[ $d][1,2,3]$ triazole $\mathbf{5 b}$ and 7-benzotriazol-1-yl-9,9-dibutylfluorene-2-sulfonic acid $\mathbf{6} \mathbf{b}$ were further confirmed by single crystal X-ray analysis and their ORTEP diagrams are shown in Figure $2 .{ }^{28}$ The fluorene ring is slightly puckered and benzotriazole ring is planar, and the two rings are twisted with a dihedral angle of $43.5^{\circ}$ and $25.3^{\circ}$ for $\mathbf{5 b}$ and $\mathbf{6 b}$, respectively. It also shows that the protons of the methyl group $\left(-\mathrm{CH}_{2} \mathrm{CH}_{2} \mathrm{CH}_{2} \mathrm{CH}_{3}\right)$ and the methylene group $\left(-\mathrm{CH}_{2} \mathrm{CH}_{2} \mathrm{CH}_{2} \mathrm{CH}_{3}\right)$ separated by one carbon to the methyl group lie above the carbon atoms of the aromatic ring, justifying the aforementioned up-field shifts of those protons in the ${ }^{1} \mathrm{H}$ NMR spectra.

\section{Conclusions}

New fluorene derivatives 5a-b having benzotriazole as a substituent were prepared via in situ formation of the heterocyclic ring, starting from 2-nitrofluorene. Sulfonation of 5a-b with concentrated sulfuric acid yielded 7-benzotriazol-1-ylfluorene-2-sulfonic acids 6a-b. Their structures were characterized by ${ }^{1} \mathrm{H}$ NMR, ${ }^{13} \mathrm{C}$ NMR, and elemental analysis, and the structures of $\mathbf{5 b}$ and $\mathbf{6 b}$ were further confirmed by single crystal $\mathrm{X}$-ray analysis. Fluorene derivatives and benzotriazole compounds are known to have various useful photophysical and biological properties, respectively, and thus the fluorene derivatives having benzotriazole substituent prepared in this study are expected to exhibit interesting characteristics.

\section{Experimental}

General. Melting points are uncorrected. ${ }^{1} \mathrm{H}$ and ${ }^{13} \mathrm{C}$ NMR spectra were obtained at 400 and $100 \mathrm{MHz}$, respectively, using tetramethylsilane (in $\mathrm{CDCl}_{3}$ ) or residual undeuterated solvent (in DMSO- $d_{6}$ and $\mathrm{CD}_{2} \mathrm{Cl}_{2}$ ) as an internal standard. Elemental analyses were carried out at Chungnam National University Center for Research Facilities.

Preparation of 2-amino-9,9-dibutylfluorene 2a-b. 2-Nitrofluorene $\mathbf{1 a}$ or $\mathbf{1} \mathbf{b}^{13}(1.0 \mathrm{~g})$ in methanol $(10 \mathrm{~mL})$ was reacted with atmospheric hydrogen gas in the presence of $5 \% \mathrm{Pd} / \mathrm{C}$ $(0.50 \mathrm{~g})$ at room temperature for $5 \mathrm{~h}$. The reaction mixture was filtered, concentrated, and then purified by silica gel column chromatography (eluent : hexane : ethyl acetate $=4: 1$ for $\mathbf{2 a}$; hexane-ethyl acetate $=30: 1$ and then ethyl acetate for $\mathbf{2 b}$ ) to give 2-aminofluorenes (2a: $0.73 \mathrm{~g}, 85 \%$; $2 \mathbf{b}: 0.88 \mathrm{~g}, 96 \%$ ) as pale yellow solids. 2a is also commercially available.

2a: $\mathrm{mp} 133 \sim 134^{\circ} \mathrm{C}\left(\mathrm{lit}^{29} 128 \sim 129{ }^{\circ} \mathrm{C}\right.$ ); ${ }^{1} \mathrm{H}$ NMR (DMSO- $d_{6}$, residual solvent peak $\delta=2.50) \delta 3.73(\mathrm{~s}, 2 \mathrm{H}), 5.19(\mathrm{~s}, 2 \mathrm{H}), 6.59$ $(\mathrm{d}, 1 \mathrm{H}, J=8.0 \mathrm{~Hz}), 6.77(\mathrm{~s}, 1 \mathrm{H}), 7.10(\mathrm{t}, 1 \mathrm{H}, J=7.4 \mathrm{~Hz}), 7.25$ $(\mathrm{t}, 1 \mathrm{H}, J=7.2 \mathrm{~Hz}), 7.42(\mathrm{~d}, 1 \mathrm{H}, J=7.6 \mathrm{~Hz}), 7.50(\mathrm{~d}, 1 \mathrm{H}, J=$ $8.0 \mathrm{~Hz}$ ), $7.59(\mathrm{~d}, 1 \mathrm{H}, J=7.6 \mathrm{~Hz}) ;{ }^{13} \mathrm{C}$ NMR (DMSO- $d_{6}$, solvent peak $\delta=39.5) \delta 36.2,110.4,112.8,117.9,120.5,124.3,124.7$, 126.5, 129.6, 141.6, 142.3, 144.6, 148.4.

2b: $\mathrm{mp} 93 \sim 94{ }^{\circ} \mathrm{C} ;{ }^{1} \mathrm{H}$ NMR $\left(\mathrm{CDCl}_{3}\right) \delta 0.54-0.70(\mathrm{~m}, 4 \mathrm{H})$, 0.67 (t, $6 \mathrm{H}, J=7.2 \mathrm{~Hz}$ ), 1.07 (sextet, $4 \mathrm{H}, J=7.2 \mathrm{~Hz}$ ), 1.82$1.97(\mathrm{~m}, 4 \mathrm{H}), 3.69$ (broad s, $2 \mathrm{H}), 6.66(\mathrm{dd}, 1 \mathrm{H}, J=8.4,2.0 \mathrm{~Hz}$ ), $6.67(\mathrm{~s}, 1 \mathrm{H}), 7.18(\mathrm{t}, 1 \mathrm{H}, J=7.2 \mathrm{~Hz}), 7.24-7.28(\mathrm{~m}, 2 \mathrm{H}), 7.48(\mathrm{~d}$, $1 \mathrm{H}, J=8.0 \mathrm{~Hz}), 7.54(\mathrm{~d}, 1 \mathrm{H}, J=8.0 \mathrm{~Hz}),{ }^{13} \mathrm{C}$ NMR $\left(\mathrm{CDCl}_{3}\right)$ $\delta 13.8,23.1,25.9,40.4,54.7,109.9,114.0,118.3,120.4,122.5$, 125.3, 126.5, 132.6, 141.5, 145.7, 149.7, 152.6. Anal. Calcd for $\mathrm{C}_{21} \mathrm{H}_{27} \mathrm{~N}$ : C, 85.95; H, 9.27; N, 4.77. Found: C, 86.33; H, $9.51 ; \mathrm{N}, 4.86$.

Preparation of 2-( $\mathrm{N}-2,4$-dinitrophenyl)aminofluorene compounds 3a-b. To a stirred solution of 2a-b (0.5 g) in DMSO $(5.0 \mathrm{~mL})$ was added 2,4-dinitrofluorobenzene (1.1 molar ratio) under a nitrogen atmosphere and stirring was continued for $4 \mathrm{~h}$ at room temperature. The reaction mixture was diluted with cold water $(20 \mathrm{~mL})$, and then filtered. The collected precipitate was washed with cold water and then cold methanol, and dried under vacuum to give 2-(N-2,4-dinitrophenyl)aminofluorene compounds (3a: $0.87 \mathrm{~g}, 90 \%$; 3b: $0.76 \mathrm{~g}, 97 \%$ ) as pale yellow solids.

3a: $\mathrm{mp} 220 \sim 223{ }^{\circ} \mathrm{C} ;{ }^{1} \mathrm{H}$ NMR $\left(\mathrm{CD}_{2} \mathrm{Cl}_{2}\right.$, residual solvent peak $\delta=5.32) \delta 3.98(\mathrm{~s}, 2 \mathrm{H}), 7.23(\mathrm{~d}, 1 \mathrm{H}, J=9.6 \mathrm{~Hz}), 7.33-$ $7.38(\mathrm{~m}, 2 \mathrm{H}), 7.42$ (t, 1H, $J=7.6 \mathrm{~Hz}), 7.51$ (s, 1H), 7.60 (d, 
$1 \mathrm{H}, J=7.6 \mathrm{~Hz}), 7.83(\mathrm{~d}, 1 \mathrm{H}, J=7.2 \mathrm{~Hz}), 7.90(\mathrm{~d}, 1 \mathrm{H}, J=8.0$ $\mathrm{Hz}), 8.16(\mathrm{dd}, 1 \mathrm{H}, J=9.2,2.8 \mathrm{~Hz}), 9.15(\mathrm{~d}, 1 \mathrm{H}, J=2.8 \mathrm{~Hz})$, 10.05 (broad s, $1 \mathrm{H}) ;{ }^{13} \mathrm{C} \mathrm{NMR}\left(\mathrm{CD}_{2} \mathrm{Cl}_{2}\right.$, solvent peak $\left.\delta=53.8\right)$ $\delta 37.3,116.7,120.4,121.4,122.6,124.3,124.6,125.5,127.3$, 127.6, 130.1, 131.4, 135.6, 137.5, 140.8, 141.5, 143.8, 145.7, 147.7. Anal. Calcd for $\mathrm{C}_{19} \mathrm{H}_{13} \mathrm{~N}_{3} \mathrm{O}_{4}$ : C, 65.70; H, 3.77; N, 12.10 . Found: C, 65.72; H, 4.15; N, 11.95 .

3b: mp $193 \sim 194{ }^{\circ} \mathrm{C} ;{ }^{1} \mathrm{H}$ NMR $\left(\mathrm{CD}_{2} \mathrm{Cl}_{2}\right.$, residual solvent peak $\delta=5.32) \delta 0.62$ (quintet, $4 \mathrm{H}, J=8.0 \mathrm{~Hz}$ ), $0.69(\mathrm{t}, 6 \mathrm{H}, J=$ $7.6 \mathrm{~Hz}$ ), 1.10 (sextet, $4 \mathrm{H}, J=7.4 \mathrm{~Hz}$ ), 1.93-2.07 (m, 4H), 7.21 $(\mathrm{d}, 1 \mathrm{H}, J=9.6 \mathrm{~Hz}), 7.29-7.31(\mathrm{~m}, 2 \mathrm{H}), 7.35-7.41(\mathrm{~m}, 3 \mathrm{H}), 7.75$ $(\mathrm{d}, 1 \mathrm{H}, J=8.0 \mathrm{~Hz}), 7.82(\mathrm{~d}, 1 \mathrm{H}, J=8.8 \mathrm{~Hz}), 8.16(\mathrm{dd}, 1 \mathrm{H}, J=$ 9.6, $2.8 \mathrm{~Hz}), 9.16(\mathrm{~d}, 1 \mathrm{H}, J=2.8 \mathrm{~Hz}), 10.06($ broad s, $1 \mathrm{H}) ;{ }^{13} \mathrm{C}$ NMR $\left(\mathrm{CD}_{2} \mathrm{Cl}_{2}\right.$, solvent peak $\left.\delta=53.8\right) \delta 14.0,23.3,26.4,40.3$, 55.7, 116.7, 120.2, 120.6, 121.3, 123.4, 124.4, 124.6, 127.4, $128.0,130.1,131.5,136.0,137.7,140.3,141.1,147.8,151.2$, 153.4. Anal. Calcd for $\mathrm{C}_{27} \mathrm{H}_{29} \mathrm{~N}_{3} \mathrm{O}_{4}$ : C, 70.57; H, 6.36; N, 9.14. Found: C, 70.96; H, 6.17; N, 9.15.

Preparation of 1-(fluoren-2-yl)-benzo $[d][1,2,3]$ triazoles 5a-b. 2-( $N$-2,4-Dinitrophenyl)aminofluorene compounds $\mathbf{3 a - b}(0.50$ $\mathrm{g})$ in methanol $(10 \mathrm{~mL})$ was reacted with atmospheric hydrogen gas in the presence of $5 \% \mathrm{Pd} / \mathrm{C}(0.25 \mathrm{~g})$ at room temperature for $5 \mathrm{~h}$. Filtration and concentration of the reaction mixture gave 4a-b, which was used in the next step without further purification.

4a: ${ }^{1} \mathrm{H}$ NMR (DMSO- $d_{6}$, residual solvent peak $\left.\delta=2.50\right) \delta$ $3.72(\mathrm{~s}, 2 \mathrm{H}), 4.48$ (broad s, 2H), 4.69 (broad s, 2H), 5.87 (dd, $1 \mathrm{H}, J=8.4,2.4 \mathrm{~Hz}), 6.03(1 \mathrm{H}, \mathrm{d}, J=2.4 \mathrm{~Hz}), 6.59(\mathrm{dd}, 1 \mathrm{H}, J=$ $8.0,1.6 \mathrm{~Hz}), 6.65(\mathrm{~d}, 1 \mathrm{H}, J=8.0 \mathrm{~Hz}), 6.67(\mathrm{~s}, 1 \mathrm{H}), 6.93(\mathrm{~s}, 1 \mathrm{H})$, $7.10(\mathrm{t}, 1 \mathrm{H}, J=7.4 \mathrm{~Hz}), 7.25(\mathrm{t}, 1 \mathrm{H}, J=7.4 \mathrm{~Hz}), 7.42(\mathrm{~d}, 1 \mathrm{H}$, $J=7.2 \mathrm{~Hz}), 7.53(\mathrm{~d}, 1 \mathrm{H}, J=8.4 \mathrm{~Hz}), 7.60(\mathrm{~d}, 1 \mathrm{H}, J=7.6 \mathrm{~Hz})$; ${ }^{13} \mathrm{C}$ NMR (DMSO- $d_{6}$, solvent peak $\left.\delta=39.5\right) \delta 36.3,100.6$, 103.6, 109.1, 112.2, 116.3, 118.0, 120.3, 124.3, 124.7, 126.5, $128.1,130.1,141.7,142.1,144.4,145.2,147.0,148.4$.

4b: ${ }^{1} \mathrm{H}$ NMR (DMSO- $d_{6}$, residual solvent peak $\left.\delta=2.50\right) \delta$ 0.43-0.63 (m, 4H), $0.64(\mathrm{t}, 6 \mathrm{H}, J=7.2 \mathrm{~Hz}$ ), 1.03 (sextet, $4 \mathrm{H}$, $J=7.2 \mathrm{~Hz}$ ), 1.72-1.92 (m, 4H), 4.47 (broad s, 2H), 4.67 (broad $\mathrm{s}, 2 \mathrm{H}), 5.86(\mathrm{~d}, 1 \mathrm{H}, J=8.0 \mathrm{~Hz}), 6.03(\mathrm{~s}, 1 \mathrm{H}), 6.50(\mathrm{~d}, 1 \mathrm{H}, J=$ $8.0 \mathrm{~Hz}), 6.60(\mathrm{~s}, 1 \mathrm{H}), 6.67(\mathrm{~d}, 1 \mathrm{H}, J=8.0 \mathrm{~Hz}), 6.90(\mathrm{~s}, 1 \mathrm{H}), 7.10$ $(\mathrm{t}, 1 \mathrm{H}, J=7.4 \mathrm{~Hz}), 7.19(\mathrm{t}, 1 \mathrm{H}, J=7.2 \mathrm{~Hz}), 7.28(\mathrm{~d}, 1 \mathrm{H}, J=7.2$ $\mathrm{Hz}), 7.44(\mathrm{~d}, 1 \mathrm{H}, J=8.0 \mathrm{~Hz}), 7.51(\mathrm{~d}, 1 \mathrm{H}, J=7.6 \mathrm{~Hz}) ;{ }^{13} \mathrm{C} \mathrm{NMR}$ (DMSO- $d_{6}$, solvent peak $\left.\delta=39.5\right) \delta 13.8,22.5,25.8,39.6$, 54.0, 100.8, 103.6, 107.3, 112.0, 116.6, 117.8, 120.3, 122.3, $124.7,126.6,126.9,129.5,141.6,144.6,146.6,148.1,149.0$, 151.4 .

4a-b $(0.33 \mathrm{~g})$ was added to an aqueous sulfuric acid solution (prepared by mixing $1 \mathrm{~mL}$ of $98 \mathrm{wt} \%$ sulfuric acid and $3 \mathrm{~mL}$ of distilled water), stirred at room temperature for $0.5 \mathrm{~h}$, and then cooled to $0 \sim 5{ }^{\circ} \mathrm{C}$. To this was added slowly an aqueous solution $(1.5 \mathrm{~mL})$ of $\mathrm{NaNO}_{2}(2.5$ molar ratio), stirred for $0.5 \mathrm{~h}$, and then added $\mathrm{H}_{3} \mathrm{PO}_{2}(50 \mathrm{wt} \%, 5.0 \mathrm{~mL})$ and stirred for $6 \mathrm{~h}$ maintaining the temperature at $0 \sim 5{ }^{\circ} \mathrm{C}$. After further stirring at room temperature for $16 \mathrm{~h}$, the reaction mixture was diluted with distilled water $(10 \mathrm{~mL})$ and then extracted with dichloromethane $(4 \times 20 \mathrm{~mL})$. The combined organic layers were dried, concentrated, and then purified by column chromatography (eluent : hexane : ethyl acetate $=4: 1$ for $\mathbf{5 a} ; 10: 1$ for $\mathbf{5 b}$ ) to give 1-(fluoren-2-yl)-benzo[ $d][1,2,3]$ triazoles (5a: $0.13 \mathrm{~g}, 32 \%$ based on 3a; $5 \mathbf{b}$ : $0.13 \mathrm{~g}, 30 \%$ based on $\mathbf{3 b}$ ) as pale yellow solids.

5a: $\mathrm{mp} 150 \sim 152{ }^{\circ} \mathrm{C} ;{ }^{1} \mathrm{H}$ NMR (DMSO- $d_{6}$, residual solvent peak $\delta=2.50) \delta 4.10(\mathrm{~s}, 2 \mathrm{H}), 7.39(\mathrm{dt}, 1 \mathrm{H} J=7.6,1.2 \mathrm{~Hz})$, $7.45(\mathrm{t}, 1 \mathrm{H}, J=7.6 \mathrm{~Hz}), 7.53(\mathrm{t}, 1 \mathrm{H}, J=7.6 \mathrm{~Hz}), 7.64-7.69(\mathrm{~m}$, 2H), 7.89 (dd, $1 \mathrm{H}, J=8.0,2.0 \mathrm{~Hz}), 7.99$ (t, $1 \mathrm{H}, J=8.4 \mathrm{~Hz}), 8.03$ $(\mathrm{d}, 1 \mathrm{H}, J=8.0 \mathrm{~Hz}), 8.08(\mathrm{~d}, 1 \mathrm{H}, J=2.0 \mathrm{~Hz}), 8.19(\mathrm{~d}, 1 \mathrm{H}, J=$ $8.0 \mathrm{~Hz}), 8.20(\mathrm{~d}, 1 \mathrm{H}, J=8.4 \mathrm{~Hz}) ;{ }^{13} \mathrm{C}$ NMR (DMSO- $d_{6}$, solvent peak $\delta=39.5) \delta 36.7,111.1,119.7,119.9,120.6,121.2,121.8$, 124.7, 125.3, 127.0, 127.5, 128.7, 132.0, 134.9, 140.0, 141.6, 143.6, 144.9, 145.7; LCMS $m / z$ (relative intensity), 113.2 (6), 282.3 (6), $284.1\left(\mathrm{MH}^{+}, 100\right), 285.1$ (20). Anal. Calcd for $\mathrm{C}_{19} \mathrm{H}_{13}$ $\mathrm{N}_{3}$ : C, 80.54; H, 4.62; N, 14.83. Found: C, 80.37; H, 4.91; N, 14.65 .

5b: mp $129 \sim 131{ }^{\circ} \mathrm{C} ;{ }^{1} \mathrm{H}$ NMR (DMSO- $d_{6}$, residual solvent peak $\delta=2.50) \delta 0.46-0.60(\mathrm{~m}, 4 \mathrm{H}), 0.61(\mathrm{t}, 6 \mathrm{H}, J=7.2 \mathrm{~Hz})$, 1.03 (sextet, $4 \mathrm{H}, J=7.2 \mathrm{~Hz}), 1.97-2.18(\mathrm{~m}, 4 \mathrm{H}), 7.37-7.40(\mathrm{~m}$, $2 \mathrm{H}), 7.47-7.50(\mathrm{~m}, 1 \mathrm{H}), 7.53(\mathrm{t}, 1 \mathrm{H}, J=7.6 \mathrm{~Hz}), 7.69(\mathrm{t}, 1 \mathrm{H}$, $J=7.6 \mathrm{~Hz}), 7.83(\mathrm{dd}, 1 \mathrm{H}, J=8.4,2.0 \mathrm{~Hz}), 7.90(\mathrm{~d}, 1 \mathrm{H}, J=8.4$ $\mathrm{Hz}), 7.92-7.95(\mathrm{~m}, 1 \mathrm{H}), 7.96(\mathrm{~d}, 1 \mathrm{H}, J=1.6 \mathrm{~Hz}), 8.10(\mathrm{~d}, 1 \mathrm{H}$, $J=8.0 \mathrm{~Hz}), 8.21(\mathrm{~d}, 1 \mathrm{H}, J=8.4 \mathrm{~Hz}) ;{ }^{13} \mathrm{C}$ NMR (DMSO- $d_{6}$, solvent peak $\delta=39.5) \delta 13.7,22.3,25.8,39.0,55.2,111.0$, 117.7, 119.7, 120.4, 121.1, 121.8, 123.0, 124.7, 127.1, 127.9, 128.7, 131.9, 135.3, 139.4, 141.1, 145.8, 150.5, 152.1; LCMS $\mathrm{m} / z$ (relative intensity), $282.3(15), 396.3\left(\mathrm{MH}^{+}, 100\right), 397.2$ (28). Anal. Calcd for $\mathrm{C}_{27} \mathrm{H}_{29} \mathrm{~N}_{3}$ : C, 81.99; H, 7.39; N, 10.62 . Found: C, 81.61; H, 7.57; N, 10.75.

Crystal data for $\mathbf{5 b}:^{28}$ crystal color, colorless; habit, plate; crystal dimensions, $0.11 \times 0.10 \times 0.03 \mathrm{~mm}^{3}$; crystal system, monoclinic; space group, $P 2_{1} / \mathrm{n}$; cell parameters, $a=8.9243(8)$ $\AA, b=25.137(2) \AA, c=10.4656(11) \AA, \alpha=90.0, \beta=98.78(1)$, $\gamma=90.0 ; \mathrm{V}=2320.2(4) \AA^{3} ; \lambda(\mathrm{Mo}-\mathrm{K} \alpha)=0.71073 \AA ; R_{1}(I>2 \sigma$ (I) $)=0.070$.

Preparation of 7-benzotriazol-1-yl-fluorene-2-sulfonic acids 6a-b. A reaction mixture of 1-(fluoren-2-yl)-benzo[ $d][1,2,3]$ triazole 5a-b $(60 \mathrm{mg})$ and concentrated sulfuric acid $(0.5 \mathrm{~mL}$, Aldrich, $99.999 \mathrm{wt} \%$ ) was stirred at room temperature for $5 \mathrm{~h}$ and then poured slowly into icy water $(5.0 \mathrm{~mL})$ to obtain precipitates. The precipitates were filtered, washed with cold water, and put in water and then basified with saturated $\mathrm{Na}_{2} \mathrm{CO}_{3}$ solution to obtain a clear solution. The solution was acidified with $2 \mathrm{~N} \mathrm{HCl}$ to produce precipitates, which were filtered, washed with water and then vacuum-dried to give $\mathbf{6 a}(60 \mathrm{mg}, 78 \%)$ as pale yellow solid. In case of $\mathbf{6 b}$, the reaction mixture diluted with icy water was extracted with ethyl acetate $(4 \times 5 \mathrm{~mL})$. The organic layers were dried, concentrated, and then purified by column chromatography (eluent : hexane : ethyl acetate $=4: 1$ ) to give $\mathbf{6 b}(70 \mathrm{mg}, 97 \%)$ as pale yellow solid.

6a: mp $287{ }^{\circ} \mathrm{C}(\mathrm{dec}) ;{ }^{1} \mathrm{H}$ NMR (DMSO- $d_{6}$, residual solvent peak $\delta=2.50) \delta 4.12(\mathrm{~s}, 2 \mathrm{H}), 7.54(\mathrm{t}, 1 \mathrm{H}, J=7.4 \mathrm{~Hz}), 7.66-7.72$ (overlapped d $+\mathrm{t}, 2 \mathrm{H}), 7.89-7.91$ (overlapped s $+\mathrm{d}, 2 \mathrm{H}), 7.99(\mathrm{~d}$, $1 \mathrm{H}, J=8.4 \mathrm{~Hz}), 8.02$ (d, $1 \mathrm{H}, J=8.4 \mathrm{~Hz}), 8.10$ (s, $1 \mathrm{H}), 8.20$ (d, $1 \mathrm{H}, J=8.0 \mathrm{~Hz}), 8.21(\mathrm{~d}, 1 \mathrm{H}, J=8.4 \mathrm{~Hz}) ;{ }^{13} \mathrm{C}$ NMR (DMSO- $d_{6}$, solvent peak $\delta=39.5) \delta 36.8,111.2,119.7,119.8,120.0,121.5$, $121.9,122.6,124.7,124.8,128.8,132.0,135.0,140.1,141.2$, 143.2, 145.6, 145.8, 147.5. Anal. Calcd for $\mathrm{C}_{19} \mathrm{H}_{13} \mathrm{~N}_{3} \mathrm{O}_{3} \mathrm{~S}_{3} \mathrm{H}_{2} \mathrm{O}$ : C, 54.67; H, 4.59; N, 10.07; S, 7.68. Found: C, 54.64; H, 4.35; N, 10.02; S, 7.70.

6b: mp $174{ }^{\circ} \mathrm{C}(\mathrm{dec}) ;{ }^{1} \mathrm{H}$ NMR (DMSO- $d_{6}$, residual solvent 
peak $\delta=2.50) \delta 0.56$ (quintet, $4 \mathrm{H}, J=7.6 \mathrm{~Hz}), 0.64(\mathrm{t}, 6 \mathrm{H}, J=$ $7.4 \mathrm{~Hz}$ ), 1.07 (sextet, $4 \mathrm{H}, J=7.6 \mathrm{~Hz}$ ), 1.98-2.18 (m, 4H), 7.54 $(\mathrm{t}, 1 \mathrm{H}, J=7.6 \mathrm{~Hz}$ ), 7.66-7.72 (overlapped s $+\mathrm{d}+\mathrm{t}, 3 \mathrm{H}), 7.84$ $(\mathrm{d}, 1 \mathrm{H}, J=8.4 \mathrm{~Hz}), 7.91(\mathrm{~d}, 2 \mathrm{H}, J=8.4 \mathrm{~Hz}), 7.98(\mathrm{~s}, 1 \mathrm{H}), 8.11(\mathrm{~d}$, $1 \mathrm{H}, J=8.4 \mathrm{~Hz}), 8.21$ (d, $1 \mathrm{H}, J=8.0 \mathrm{~Hz}) ;{ }^{13} \mathrm{C}$ NMR (DMSO- $d_{6}$, solvent peak $\delta=39.5) \delta 13.8,22.4,25.8,39.3,55.3,111.0$, $117.8,119.70,119.74,119.9,121.4,121.9,124.8,125.1,128.7$, 132.0, 135.4, 139.6, 140.6, 145.8, 148.0, 150.0, 152.7. Anal. Calcd for $\mathrm{C}_{27} \mathrm{H}_{29} \mathrm{~N}_{3} \mathrm{O}_{3} \mathrm{~S} 3 \mathrm{H}_{2} \mathrm{O}: \mathrm{C}, 61.23 ; \mathrm{H}, 6.66 ; \mathrm{N}, 7.93 ; \mathrm{S}$, 6.05. Found: C, 61.11; H, 6.67; N, 7.74; S, 6.04.

Crystal data for $6 \mathbf{b}:^{28}$ crystal color, colorless; habit, block; crystal dimensions, $0.10 \times 0.10 \times 0.05 \mathrm{~mm}^{3}$; crystal system, triclinic; space group, $P-1$; cell parameters, $a=9.5199(19) \AA$, $b=12.255(3) \AA, c=25.823(5) \AA, \alpha=79.61(3), \beta=85.49(3)$, $\gamma=77.95(3) ; \mathrm{V}=2895.3(10) \AA^{3} ; \lambda(\mathrm{Mo}-\mathrm{K} \alpha)=0.71073 \AA ; R_{1}$ $(I>2 \sigma(I))=0.175$.

Acknowledgments. This study was financially supported by research funds from Chungnam National University in 2008 to KKP.

\section{References and Note}

1. Reinhardt, B. A.; Brott, L. L.; Clarson, S. J.; Dillard, A. G.; Bhatt, J. C.; Kannan, R.; Yuan, L.; He, G. S.; Prasad, P. N. Chem. Mater. 1998, 10, 1863.

2. (a) Belfield, K. D.; Hagan, D. J.; Van Stryland, E. W.; Schafer, K. J.; Negres, R. A. Org. Lett. 1999, 1, 1575. (b) Yao, S.; Belfield, K. D. J. Org. Chem. 2005, 70, 5126.

3. Werts, M. H. V.; Gmouh, S.; Mongin, O.; Pons, T.; BlanchardDesce, M. J. Am. Chem. Soc. 2004, 126, 16294.

4. (a) Belfield, K. D.; Bondar, M. V.; Hernandez, F. E.; Masunov, A. E.; Mikhailov, I. A.; Morales, A. R.; Przhonska, O. V.; Yao, S. J. Phys. Chem. C 2009, 113, 4706. (b) Mikhailov, I. A.; Bondar, M. V.; Belfield, K. D.; Masunov, A. E. J. Phys. Chem. C 2009, 113, 20719. (c) Belfield, K. D.; Bondar, M. V.; Yanez, C. O.; Herandez, F. E.; Przhonska, O. V. J. Mater. Chem. 2009, 19, 7498.

5. Zheng, Q.; He, G. S.; Lu, C.; Prasad, P. N. J. Mater. Chem. 2005, 15,3488

6. Li, C.; Yang, K.; Feng, Y.; Su, X.; Yang, J.; Jin, X.; Shui, M.; Wang, Y.; Zhang, X.; Song, Y.; Xu, H. J. Phys. Chem. B 2009, 113,15730 .

7. Sun, M.; Ding, Y.; Zhao, L.; Ma, F. Chemical Physics 2009, 359, 166.
8. Belfield, K. D.; Bondar, M. V.; Hernandez, F. E.; Przhonska, O. V.; Yao, S. J. Phys. Chem. B 2007, 111, 12723.

9. Belfield, K. D.; Schafer, K. J.; Mourad, W.; Reinhardt, B. A. J. Org. Chem. 2000, 65, 4475.

10. Wang, Z.; Xing, Y.; Shao, H.; Lu, P.; Weber, W. P. Org. Lett. 2005, 7, 87.

11. Wang, Z.; Zheng, G.; Lu, P. Org. Lett. 2005, 7, 3669.

12. Park, K. K.; Park, J. W.; Hamilton, A. D. J. Fluoresc. 2007, 17, 361.

13. Park, K. K.; Park, J. W.; Hamilton, A. D. Org. Biomol. Chem. 2009 , 7,4225 .

14. Kucherak, O. A.; Didier P.; Mely, Y.; Klymchenko, A. S. J. Phys. Chem. Lett. 2010, 1, 616.

15. Morales, A. R.; Yanez, C. O.; Schafer-Hales, K. J.; Marcus, A. I.; Belfield, K. D. Bioconjugate Chem. 2009, 20, 1992.

16. Morales, A. R.; Schafer-Hales, K. J.; Yanez, C. O.; Bondar, M. V.; Przhonska, O. V.; Marcus, A. I.; Belfield, K. D. ChemPhysChem 2009, 10, 2073.

17. Kotaka, H.; Konishi, G.; Mizuno, K. Tetrahedron Lett. 2010, 51, 181.

18. Du, C.; Ye, S.; Chen, J.; Guo, Y.; Liu, Y.; Lu, K.; Liu, Y.; Qi, T.; Gao, X.; Shuai, Z.; Gui, Y. Chem. Eur. J. 2009, 15, 8275.

19. Omer, K. M.; Kanibolotsky, A. L.; Skabara, P. J.; Perepichka, I. F.; Bard, A. J. J. Phys. Chem. B 2007, 111, 6612.

20. Wong, K.; Chen, Y.; Lin, Y.; Su, H.; Wu, C. Org. Lett. 2005, 7, 5361.

21. Ranger, M.; Rondeau, D.; Leclerc, M. Macromolecules 1997, 30, 7686.

22. Hamilton, G. S.; Mewshaw, R. E.; Bryant, C. M.; Feng, Y.; Endemann, G.; Madden, K. S.; Janczak, J. E.; Perumattam, J.; Stanton, L. W.; Yang, X.; Yin, Z.; Venkataramen, B.; Liu, D. Y. J. Med. Chem. 1995, 38, 1650.

23. Lee, C.-W.; Kung, M.-P.; Hou, C.; Kung, H. F. Nuclear Med. Biol. 2003, 30, 573 .

24. Najda-Bernatowicz, A.; Lebska, M.; Orzeszko, A.; Kopanska, K.; Krzywinska, E.; Muszynska, G.; Bretner, M. Bioorg. Med. Chem. 2009, 17, 1573.

25. Bovens, S.; Kaptur, M.; Elfringhoff, A. S.; Lehr, M. Bioorg. Med. Chem. Lett. 2009, 19, 2107.

26. Rezaei, Z.; Khabnadideh, S.; Pakshir, K.; Hossaini, Z.; Amiri, F. European J. Med. Chem. 2009, 44, 3064.

27. Pavia, D. L.; Lampman, G. M.; Kriz, G. S. Intoduction to Spectroscopy, 3rd ed.; Harcourt College Publishers: 2001; (a) pp 125-127. (b) $\mathrm{pp}$ 270-274.

28. Detailed X-ray crystallographic data are available from the Cambridge Crystallographic Data Center, 12 Union Road, Cambridge CB2 2EZ, UK; for compound $\mathbf{5 b}$ (CCDC 765999) and for compound $\mathbf{6 b}$ (CCDC 766000).

29. Fletcher, T. L.; Namkung, M. J. J. Org. Chem. 1970, 35, 4231. 